See discussions, stats, and author profiles for this publication at: https://www.researchgate.net/publication/325553034

Dispatchable hydrogen production by multiple electrolysers to provide clean fuel and responsive demand in Libya

Conference Paper · June 2018

DOI: 10.1109/REC.2018.8362450

\section{CITATIONS}

0

2 authors:

Abdulla Rahil

University of South Wales

10 PUBLICATIONS 18 CITATIONS

SEE PROFILE
READS

17

Rupert Gammon

De Montfort University

20 PUBLICATIONS 140 CITATIONS

SEE PROFILE

Some of the authors of this publication are also working on these related projects:

Project My Electric Avenue View project

Project ESCoBox View project 


\title{
Dispatchable Hydrogen production by multiple electrolysers to provide clean fuel and responsive demand in Libya
}

\author{
Abdulla Rahil ${ }^{1,2}$, Rupert Gammon ${ }^{1}$, and Neil Brown ${ }^{1}$ \\ ${ }^{1}$ Institute of Energy and Sustainable Development, DMU, Leicester, UK' \\ 2 P13063959@my365.dmu.ac.uk
}

\begin{abstract}
The use of hydrogen as a fuel carries major environmental advantages because there are a number of ways of producing it by low-carbon methods. When electrolysis is used, additional benefits are obtained by flexible operation that offers the opportunity to reduce the cost of hydrogen production by absorbing electricity during off-peak hours, and stopping operation during peak hours. This can also act as a tool in support of balancing electrical systems. In this research, off-peak electricity is used to produce hydrogen via electrolysis, which is sold as a fuel at six garage forecourts in Darna, a small city on the east coast of Libya. In addition to the six forecourt electrolysers, a centralised electrolyser plant will be included in the system to consume the surplus energy and to satisfy any deficiency in hydrogen production at the forecourt. The capital cost of both forecourt and centralised electrolyser systems, plus fixed costs, were financed by bank loans at a $5 \%$ rate of interest over seven years. A MATLAB model with optimisation tools was used to formulate this problem. This research shows that forecourt hydrogen production at off-peak times (and without the centralised electrolyser) can satisfy nearly $53.93 \%$ of the fuel demand. This represents $59.82 \%$ of the total surplus renewable energy. The average hydrogen sale price at the forecourts is between $£ 10.82-11.71 / \mathrm{kg}$. After adding the centralised electrolyser, nearly $78.83 \%$ of the total surplus power was absorbed and the average hydrogen selling prices were between £15.04-19.80/kg The centralised electrolyser can meet $43 \%, 49 \%$, $50 \%, 42 \%, 57 \%$ and $53 \%$ of the deficit in consumption for stations $1,2,3,4,5$ and 6 , respectively.
\end{abstract}

Keywords - electrolysis; flexible operation; centralised electrolyser; styling; surplus power

\section{INTRODUCTION}

Many researches have investigated the idea of using electrolysers to tackle the variability of renewable energy generation, to supply grid services, and make money due to differences in electricity prices between peak and off-peak [1], [2], [3]. These studies prove that there are possibilities for electrolysers to consume electricity at off-peak periods for hydrogen production with different electricity markets and electricity rate structures, as well as absorbing excess renewable energy. The produced hydrogen from electricity systems with high penetration of wind energy has been widely studied, since these systems need a high level of flexibility to accommodate the variability of $r$ generation [4]. Hydrogen is commonly proposed as a means of energy storage that can support the integration of renewable power sources into electricity networks [5]. Producing hydrogen from surplus energy was investigated for use in Ireland by Troncoso, Newborough and Gonzalez et al. [6]. Gonzalez et al. indicated that a cheap electricity price and an expensive hydrogen sale price is required to create a profit, whereas Troncoso and Newborough point out that profitability can be achieved if a certain amount of on-peak electricity is also absorbed to better amortize the device's costs[7], [8]. Mansilla et al. noticed a possible cost reduction in the hydrogen when operating alkaline electrolysers intermittently in order to increase the benefits of lower electricity prices. Advances in modelling intermittent electrolyser operation are suggested in this paper, which uses Libya as an example of a country with good renewable resources and a need to modernize its energy system to a more sustainable model.

Floch et al. investigated hydrogen production using an alkaline electrolyser with power consumption restricted to offpeak times. From this, they concluded that the widely-spread price structure can lower the cost of hydrogen production, despite the difficulty in quantifying such volatility that otherwise acts as a complicating factor in electrolyser operation [9]. The $563 \mathrm{MW}$ wind-hydrogen connected to storage model was tested in Canada. The hydrogen price extracted from this scenario is $9.00 \$ / \mathrm{kgH}_{2}$, if the investment cost of wind turbine is included in the total cost of the system, and $3.37 \$ / \mathrm{kg} \mathrm{H}_{2}$ if the cost is excluded. In coming years, it is expected that a considerable transition from the combustion engine fueled by traditional fuels to electric cars will happen. Hydrogen may play a substantial role in this move. Automobile manufactures have made a clear progress in the development of fuel cell vehicles and are targeting initial marketing during the 20152017 period [10]. As the anticipated fuel for the transportation sector, hydrogen allows for the operation of cars with fast fueling and zero carbon release, which not possible with other types of zero-emission transport, such as battery-only electric vehicles [11]. In 2013, nearly 58 hydrogen refueling stations were installed in the United States (including private stations). Most were built to enhance research and demonstration projects aimed at further improving hydrogen refueling stations and providing insights into accelerating the uptake electric

978-1-5090-6751-0/17/\$31.00 C2018 IEEE 
vehicles. [12]. The work in this paper will combine two key aspects, which are: first, work on maintaining balance or grid stability by absorbing excess energy within the high penetration of renewable energy scenario. Second, the use of this energy to produce hydrogen, which will be used as fuel instead of conventional fuels and ensure there no interruption to fuel supply services. The study will focus on this scenario from an economic perspective. In other words, it will ensure good economic returns for all parties (electricity producer, electrolysis's owner and hydrogen fueling station's customers).

\section{RENEWBLE ENERGY PENETRATION AND ENERGY STORAGE}

Libya has considerable potential for producing renewable power from its solar and wind resources according to recent available data. Libya has a massive land area of $1,759,540 \mathrm{~km}^{2}$ with a long coastline of nearly $2000 \mathrm{~km}^{2}$ ( $88 \%$ of its territory) desert coverage [13].

Generally, average wind speeds fluctuate between 5 and 10 $\mathrm{m} / \mathrm{s}$ in many Libyan regions. The target of the Renewable Energy Authority in Libya is to increase the share of renewable power compared to conventional power to $30 \%$ by the year 2030. The integration of renewable energy sources into the Libyan grid will lead to instability within the grid, and energy storage should be used to tackle this problem.

\section{ELECTRICITY GENERATION}

Due to lack of data (electricity demand, fuel demand), this research will only focus on Darna, which is a small coastal city $\left(32^{\circ} 46^{I} N 22^{\circ} 38^{t} E\right)$ with a high potential for wind power (average speed $8-8.5 \mathrm{~m} / \mathrm{s}$ ). Some wind power farms have already been installed in Darna (60 MW), with another 60MW installation planned in the future. The assumption of this paper is that around $6 \%$ of the total energy consumption will be supplied via renewable energy (mainly wind power). Any excess power will be injected into an electrolyser to produce clean fuel. The explanation for this surplus energy extraction is widely presented in [14], [15]. The main steps of this section include:

- $\quad$ assume $6 \%$ of the Libyan electricity system is to be generated via renewable energy (mainly wind power);

- $\quad$ size the system using Libyan demand and wind turbine capacity factor;

- $\quad$ extract the daily surplus power;

Fig. 2 below shows the daily demand, generation and surplus energy over a year:

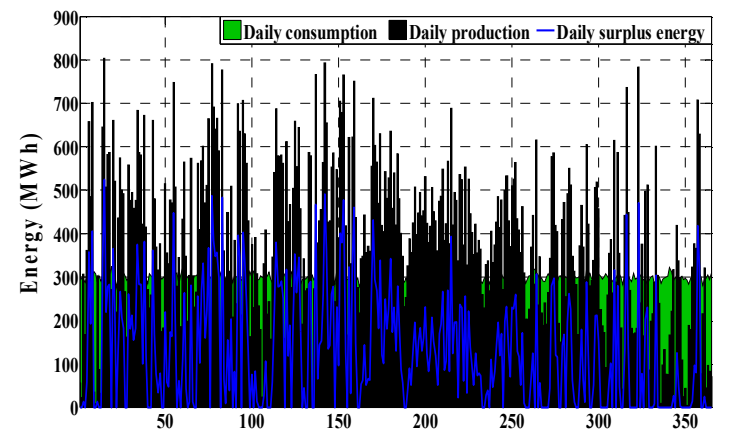

Fig. 1 Summary of the demand-supply sizing and surplus energy extraction

\section{FUEL CONSUMPTION AND HYDROGEN CONSUMPTION} SIMULATION:

\section{A. Libyan oil and natural gas (production and consumption)}

Nearly $30 \%$ of production is consumed locally. Changing to hydrogen fuel will increase the export of oil. After the civil war in 2011, production dropped to nearly 300,000 barrel/day (compared to 1,450,000 barrel/day before 2011) and the petrol price fell dramatically from $120 \$$ /barrel in 2014 to less than $50 \$ /$ barrel in 2016 .

\section{B. Fuel consumption in Daran}

There are six fuel stations located in the city of Darna. The data of fuel consumption was extracted from the stations owners' daily records. Average fuel consumption of these stations was 22,788 liters/day, 32,495 liters/day, 68,010 liters/day, 41,720 liters/day, 111,490 liters/day, and 56,485 liters/day for stations 1 to 6 , respectively.

\section{Hydrogen consumption simulation}

The estimated demand on the hydrogen refueling station is based on the current petrol stations' data. Our work assumes that $20 \%$ of all cars will be fueled by hydrogen. Based on the data presented by the U.S. department of energy, one gallon of gasoline has about the same energy as one kilogram of hydrogen. This assumption can be used to convert the daily fuel consumption data into daily hydrogen consumption. Alternatively, the formula (1) below, based on the hydrogen and gasoline engines efficiencies and lower heating values of gasoline and hydrogen, can be applied to produce the daily hydrogen consumption [16].

$$
Q_{H 2}=\frac{Q_{f f} \times L H V_{f f} \times \mu_{f f}}{L H V_{H 2} \times \mu_{H 2}}
$$

Where: $\mathcal{F}_{h}$ is the fossil fuel demand, $\Delta H W_{h}$ is the lower heating value $(\mathrm{kWh} / \mathrm{kg})$ of fossil fuel, $\mu_{/ /}$is the efficiency of a fossil fuel engine, $E H V_{m s}$ is the lower heating value of hydrogen, and $\mu_{m}$ is the efficiency of the hydrogen engine. Fig. 3 shows the hydrogen consumption on certain days in stations 1-6.

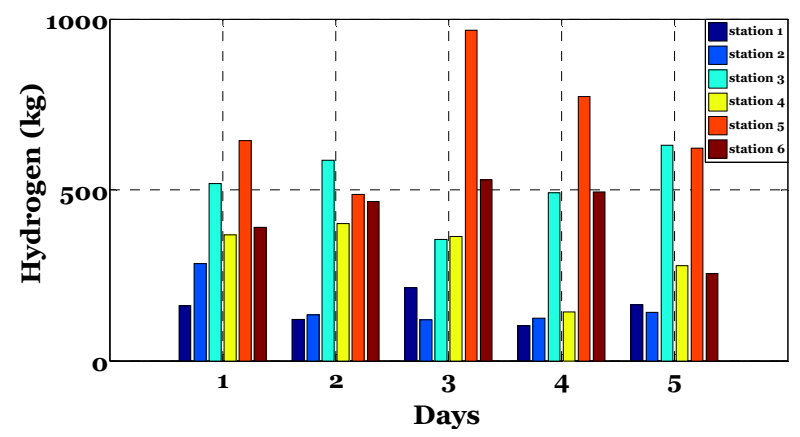

Fig. 2 daily hydrogen consumption

\section{Garage forecourt components and cost}

1) System size

The size of the garage forecourts components will be designed based on the daily fuel consumption of stations in 
Darna. Each garage forecourt comprises an electrolyser, compressor, storage and a dispenser. The size of these components is chosen as follows:

Electrolyser: the size of each electrolyser is sized based on the average consumption of hydrogen during the year. Storage: the tank design is based on the long period during the year without any surplus power, which is nearly five continuous days. Compressor: nearly one day's production is assumed for the compressor size. Dispenser: three dispensers per station are assumed to be installed. This paper will investigate two scenarios, those of running the garage forecourts without any external source of hydrogen to meet any shortage in consumption, and adding a central electrolyser to cover the shortage periods. As a result, the size and cost of the central electrolyser has been estimated. The central electrolyser system consists of the electrolyser, storage and compressor. The size of these components is chosen as follows:

Electrolyser: the size of central electrolyser is sized based on the daily production of all garage forecourts. Storage: the storage is based on the highest cumulative shortage of hydrogen consumption for all six hydrogen refueling stations. Compressor: nearly one day's production is assumed for the compressor size. Based on the assumptions above, the technical details of the six garage forecourts and central electrolyser are presented in table I.

TABLE I. TECHNICAL DETAILS OF THE SIX GARAGE FORECOURTS AND CENTRAL ELECTROLYSER

\begin{tabular}{|c|c|c|c|c|c|c|}
\hline & \multirow{2}{*}{$\begin{array}{c}\text { Electrolyser } \\
\text { capacity } \\
\text { ( kg/day) }\end{array}$} & \multicolumn{3}{|c|}{ Storage size $(\mathrm{kg})$} & \multirow{2}{*}{$\begin{array}{c}\text { compressor } \\
\text { (kg/day) }\end{array}$} & \multirow[t]{2}{*}{ dispenser } \\
\hline & & $\min$ & $\max$ & current & & \\
\hline $\begin{array}{c}\text { Garage } \\
\text { forecourts } \\
1\end{array}$ & 149 & 560 & 56 & 455 & 150 & 3 \\
\hline $\begin{array}{c}\text { Garage } \\
\text { forecourts } \\
2\end{array}$ & 226 & 630 & 63 & 481 & 230 & 3 \\
\hline $\begin{array}{c}\text { Garage } \\
\text { forecourts } \\
3 \\
\end{array}$ & 449 & 1890 & 182 & 1537 & 450 & 3 \\
\hline $\begin{array}{c}\text { Garage } \\
\text { forecourts } \\
4\end{array}$ & 282 & 1190 & 112 & 927 & 290 & 3 \\
\hline $\begin{array}{c}\text { Garage } \\
\text { forecourts } \\
5 \\
\end{array}$ & 744 & 2464 & 245 & 2077 & 750 & 3 \\
\hline $\begin{array}{c}\text { Garage } \\
\text { forecourts } \\
6\end{array}$ & 372 & 1540 & 140 & 1270 & 380 & 3 \\
\hline $\begin{array}{c}\text { Central } \\
\text { electrolyser }\end{array}$ & 1500 & $\begin{array}{l}10000 \\
\end{array}$ & $\begin{array}{c}\text { no } \\
\text { limit } \\
\end{array}$ & 0 & 1600 & - \\
\hline
\end{tabular}

2) Compontes cost and economic requirements

The cost is extracted from many recent studies [17], [18], [19], [20]. The details of the costs of the garage forecourt components are given in table $\Pi$, below:

TABLE II. COST OF THE GARAGE FORECOURTS SYSTEM

\begin{tabular}{|c|c|}
\hline Electrolyser Cost (1 MW) (million pound) & 1.8 \\
\hline Electrolyser Energy Requirement (kWh/kg H2) & 54.6 \\
\hline Storage Tank Cost (\$/kW) & 730 \\
\hline Compressor Cost, $1500 \mathrm{~kg}$ (\$/compression system) & 600,000 \\
\hline Compressor Electricity requirement $(\mathrm{kWh} / \mathrm{kg} \mathrm{H} 2)$ & 2.09 \\
\hline Dispensing Cost (\$ for a system with 3 dispensers) & 67,000 \\
\hline Control and Safety Equipment (\$) & 19,000 \\
\hline
\end{tabular}

The price of hydrogen is affected by two main parts investment and operation cost (mainly, the price of electricity). The capital cost consists of the cost of all garage forecourts components' costs, and the fixed cost taking into account the loan interest rate. The operation cost includes feedstock cost, water cost and compressor electricity cost. Maintenance costs will not be added because the simulation is only run for one year (this year is one of the seven years of return of investment). The required daily cost that guarantees meeting the economic requirements of this year (bank installment and operation cost) is summarised by the following equations:

$$
\begin{aligned}
& \text { total_payment(after7yaers) } \\
& =\text { (capital }_{\text {cost }}+\text { storage }_{\text {cost }} \\
& + \text { compressor } \\
& \left.+ \text { fixed }_{\text {cost }}\right) \times(1+i r)^{(Y)} \\
& \text { daily }_{\text {payment }}=\frac{\text { payment }(\text { after } 7 \text { yaers })}{\text { number of dayperyear } \times Y} \\
& \text { total Daily Cost }=\text { daily }_{\text {payment }} \\
& + \text { daily compressorelectricity cost } \\
& + \text { daily water cost } \\
& + \text { daily electricity cost }
\end{aligned}
$$

Where $y$ is the number of years, and ir is the interest rate. The economic targets of the six garage forecourts are to meet the total cost of the system, which includes the bank installment and variable costs, to satisfy the hydrogen demand at any time and to ensure no interruption of fuel supply to fuel cell vehicles. The aim of the electricity producer's side will be to sell as much electricity as possible (up to 90\%) as long as there are customers, regardless of any other conditions. Finally, the central electrolyser target is to satisfy the annual economic requirements and make some profit, regardless of the situation on the consumption side (garage forecourts). The bank installment is fixed, so the garage forecourts and central electrolyser will focus on buying electricity at a cheap price to minimise the cost of hydrogen production.

\section{ELECTRICITY PRICE MECHANISM}

\section{A. Garage forecourts}

The cost of the hydrogen will be investigated daily. The day-ahead market has been approved as contracts between seller and buyer for the delivery of energy the following day, the electricity price is set and the trade is agreed. Based on the theory above, each station will calculate how much hydrogen it needs to produce based on the hydrogen demand and the amount of hydrogen in the tank, taking into account all constraints such as electrolysis size and storage tank limits (maximum, minimum and initial levels). Depending on the investment cost and hydrogen price target, the daily electricity price can be determined as per equation (5), below:

$$
\begin{aligned}
& \text { PriceElectric }(f / k W h) \\
& =\sum_{0}^{365}(\text { Hydrogen price }(\mathrm{E} / \mathrm{kg}) \times \text { hydrogen required }(\mathrm{kg})-\text { InvestmentDialy Cost) }(\mathrm{f})) / \text { hydrogen required }(\mathrm{kg}) \times 54.6(\mathrm{KWh} / \mathrm{kg})
\end{aligned}
$$

The hydrogen price is chosen via the garage forecourts and should be competitive in contrast with the hydrogen price at the point of sale. In this paper, the European cost targets for hydrogen generation in 2025 is $£ 4.4 / \mathrm{kg}$ was used as dealing price at time of electricity purchase. However, the European target $(£ 7.92 / \mathrm{kg})$ in 2015 was used to assess the price at the point of sale. As mentioned earlier, the electricity producer's target is to sell as much as possible (90\%) because the rest of this power will be curtailed. However, different electricity 
tariffs will be released by the garage forecourts, which will give the electricity producer the opportunity to make some profit from excess energy. In other words, the daily starting point is the most expensive price presented, and so on, until the selling target is satisfied. The selling price for all stations is the last price. Fig. 4 shows the selection price mechanism:

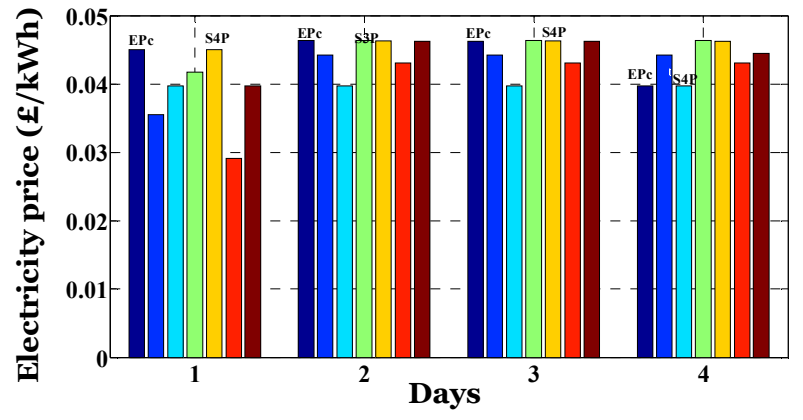

Fig. 3 the energy price mechanism

Where Epc is the electricity price, S1P to S6P are the released price of stations 1 to 6 , respectively. As can be seen, there are six stations releasing their price every day. Fig. 5 shows the yearly electricity selling price on a daily basis.

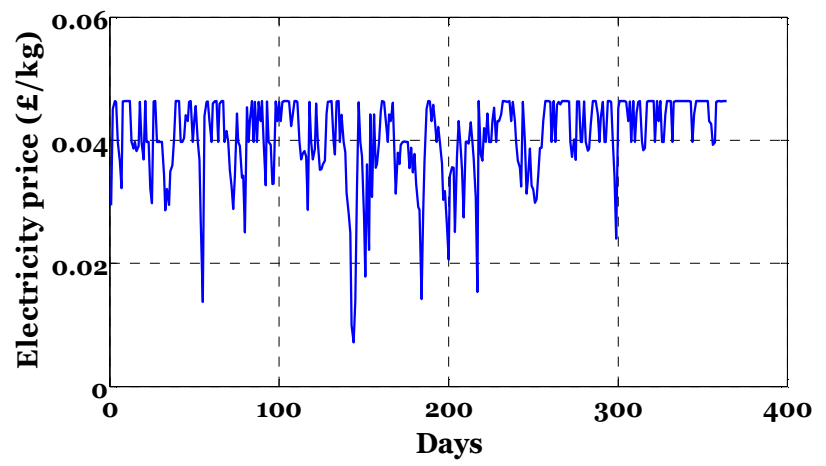

Fig. 4 daily energy prices over a year

\section{B. Central elctrolyser}

There are two possible modes of operation for the central electrolyser that will be investigated, assuming it runs at the same time as the six stations and follows the same regulations (no incentive price) and it runs after the six stations have been refueled. In the second operational mode, an incentive in terms of price of electricity can be given for the central electrolyser, such as the electricity price for the central electrolyser could be $20 \%$ less than the cheapest electricity price (even if not all the stations deal at the cheapest price) or a $20 \%$ investment could be added to the cost to guarantee a safe economic situation. In this paper, only the second mode of operation will be tested, with and without a profit margin $(20 \%$ will be added to the investment cost). Fig. 6 shows the mechanism of electricity price for the second operational mode of the central electrolyser.

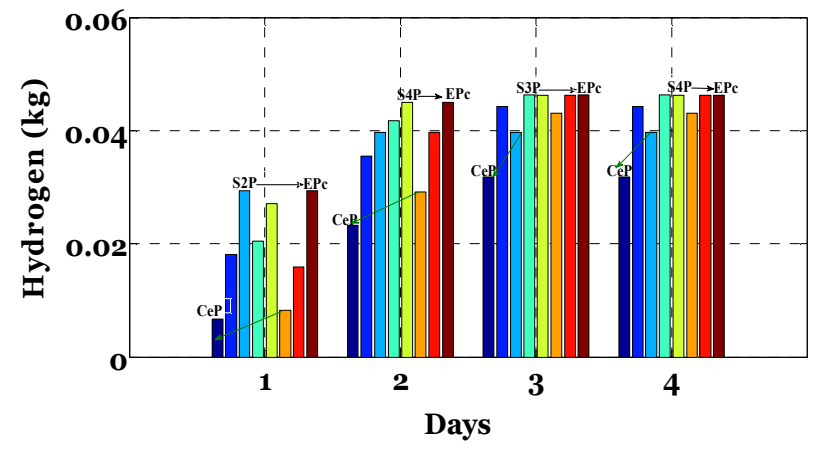

Fig. 5 the energy price mechanism

Where: $\mathrm{CeP}$ is the electricity sale price to the central electrolyser, Epc is the electricity sale price to the garage forecourts and $\mathrm{S} 2 \mathrm{P}, \mathrm{S} 3 \mathrm{P}, \mathrm{S} 4 \mathrm{P}$ and $\mathrm{S} 5 \mathrm{P}$ are the electricity releasing prices of stations $2,3,4$ and 5, respectively. Fig. 7 shows the price of central electrolyser electricity.

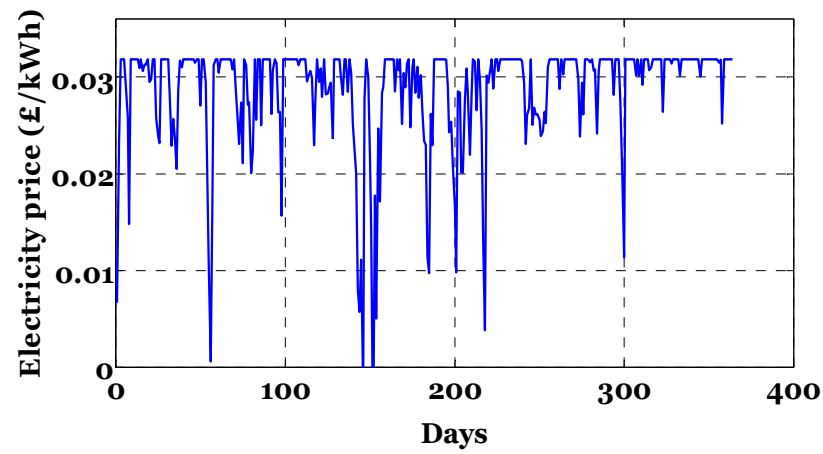

Fig. 6 daily energy price over a year

\section{SIMULATION}

All code in this paper has been written using the MATLAB software; this code includes:

Wind power calculations, which include the converting the wind speed to the desire height, calculating the capacity factor of wind turbines using Weibull parameter; many methods of calculating Weibull parameters have been applied and compared to each other, sizing the energy system based on the load data and extracting the potential excess energy, calculating the investment cost, and variable cost of the garage forecourts and central electrolyser, formulate the electricity mechanism for all scenarios and calculating the hydrogen production, hydrogen required and deficiencies in production and coding the economic assessments of all parts of the system (garage forecourts, central elctrolyser and electricity side)

\section{RESULTS}

\section{A. Garage forecourts only, without central electrolyser}

In this scenario, nearly $53.87 \%$ of the excess energy is absorbed via all garage forecourts, which satisfies nearly $59.7 \%$ of total hydrogen consumption of all cars. The garage forecourts' economic assessment is one of the most critical issues since it will determine whether this scenario is economical. Table IV below shows the economics summary of 
this scenario when $7.92 £ / \mathrm{kg}$ is considered to be the sale point price.

TABLE III. ECONOMIC ASSESSMENT OF FIRST SCENARIO

\begin{tabular}{|c|c|c|c|c|c|c|}
\hline Cost & $\begin{array}{c}\text { Investment } \\
\text { cost } \\
(\mathfrak{f} / \mathbf{y e a r})\end{array}$ & $\begin{array}{c}\text { Water } \\
\text { cost } \\
(\mathbf{f} / \text { year) }\end{array}$ & $\begin{array}{c}\text { Compressor } \\
\text { electricity } \\
\text { cost } \\
(\mathfrak{f} / \text { /year) }\end{array}$ & $\begin{array}{c}\text { Electricity } \\
\text { cost } \\
(\mathbf{f} / \text { year })\end{array}$ & $\begin{array}{c}\text { Revenue } \\
(\mathfrak{f} / \text { year) }\end{array}$ & $\begin{array}{c}\text { Difference } \\
(\mathfrak{f} / \text { /year })\end{array}$ \\
\hline $\begin{array}{c}\text { Station } \\
\mathbf{1}\end{array}$ & 291573 & 1069 & 3835 & 62225 & 247348 & -111354 \\
\hline $\begin{array}{c}\text { Station } \\
\mathbf{2}\end{array}$ & 378855 & 1313 & 4047 & 73893 & 303803 & -154305 \\
\hline $\begin{array}{c}\text { Station } \\
\mathbf{3}\end{array}$ & 915810 & 3642 & 13638 & 218559 & 842838 & -308809 \\
\hline $\begin{array}{c}\text { Station } \\
\mathbf{4}\end{array}$ & 579526 & 2207 & 8260 & 131206 & 510737 & -210461 \\
\hline $\begin{array}{c}\text { Station } \\
\mathbf{5}\end{array}$ & 1332750 & 5099 & 17376 & 294901 & 1180134 & -469991 \\
\hline $\begin{array}{c}\text { Station } \\
\mathbf{6}\end{array}$ & 753442 & 2703 & 10182 & 158992 & 625606 & -299713 \\
\hline
\end{tabular}

The difference reflects the economic situation of each garage forecourt. If the difference (revenue - total cost) is positive, this means the garage forecourts can meet their economic requirements, and vice versa in the case of a negative value. The calculation of the hydrogen cost (annual hydrogen cost / annual hydrogen production) is given in table $\mathrm{V}$ :

TABLE IV. HYDROGEN COST FOR ALL 6 HYDROGEN REFUELING STATIONS

\begin{tabular}{|c|c|c|c|c|c|c|}
\hline Station No. & station 1 & station 2 & station 3 & station 4 & station 5 & station 6 \\
\hline $\begin{array}{c}\text { Hydrogen } \\
\text { cost (£/kg) }\end{array}$ & 11.49 & 11.94 & 10.82 & 11.18 & 11.07 & 11.71 \\
\hline
\end{tabular}

The average cost of the hydrogen in all stations is higher than default price $(7.92 £ / \mathrm{kg})$.

\section{B. Garage forecourts with central electrolyser (without margin profit)}

Nearly $78.83 \%$ of surplus energy is consumed via the garage forecourts and central electrolyser systems, meeting nearly $72.07 \%$ of the total hydrogen demand. The central electrolyser hydrogen cost can be computed by dividing the total annual cost and total annual production as in table VI, below:

TABLE V. HYDROGEN PRICE OF CENTRAL ELECTROLYSER

\begin{tabular}{|c|c|}
\hline Investment cost (£/year) & 4032925 \\
\hline Water cost (£/year) & 5419 \\
\hline Compressor electricity cost (£/year) & 19941 \\
\hline Electricity cost (f/year) & 248831 \\
\hline Total hydrogen production (kg/year) & 13216 \\
\hline Average hydrogen cost (£/kg) & 32.25 \\
\hline
\end{tabular}

The economic assessment (water and compressor electricity cost was included to the total cost but not added in the table) of this scenario in Table VII and average hydrogen price for the garage forecourts is presented in Table VIII.

TABLE VI. HHYDROGEN COST ASSESMENT

\begin{tabular}{|c|c|c|c|c|c|c|}
\hline Cost & $\begin{array}{c}\text { Investment } \\
\text { cos }\end{array}$ & $\begin{array}{c}\text { Energy } \\
\text { cost }\end{array}$ & $\begin{array}{c}\text { Hydrogen } \\
\text { imported } \\
\text { cost }\end{array}$ & Revenue & $\begin{array}{c}\text { Imported } \\
\text { hydrogen } \\
\text { revenue }\end{array}$ & Difference \\
\hline $\begin{array}{c}\text { Station } \\
\mathbf{1}\end{array}$ & 291573 & 62225 & 305408 & 247348 & 75002 & -341760 \\
\hline $\begin{array}{c}\text { Station } \\
\mathbf{2}\end{array}$ & 378855 & 73893 & 588548 & 303803 & 144536 & -598317 \\
\hline $\begin{array}{c}\text { Station } \\
\mathbf{3}\end{array}$ & 915810 & 218559 & 840966 & 842838 & 206524 & -943251 \\
\hline $\begin{array}{c}\text { Station } \\
\mathbf{4}\end{array}$ & 579526 & 131206 & 436069 & 510737 & 107090 & -539440 \\
\hline
\end{tabular}

\begin{tabular}{|c|c|c|c|c|c|c|}
\hline $\begin{array}{c}\text { Station } \\
\mathbf{5}\end{array}$ & 1332750 & 294901 & 2048001 & 1180134 & 502948 & -2015046 \\
\hline $\begin{array}{c}\text { Station } \\
\mathbf{6}\end{array}$ & 753442 & 158992 & 887983 & 625606 & 218071 & -969626 \\
\hline
\end{tabular}

TABLE VII. HHYDROGEN COST ASSESMENT

\begin{tabular}{|c|c|c|c|c|c|c|}
\hline Station No. & station & station & station & station & station & station \\
& $\mathbf{1}$ & $\mathbf{2}$ & $\mathbf{3}$ & $\mathbf{4}$ & $\mathbf{5}$ & $\mathbf{6}$ \\
\hline $\begin{array}{c}\text { Hydrogen } \\
\text { cost }(\mathbf{f} / \mathbf{k g})\end{array}$ & 16.32 & 18.49 & 15.04 & 14.84 & 17.40 & 17.02 \\
\hline
\end{tabular}

The hydrogen in the tank of the central electrolyser is shown in Fig. 9. The variation of hydrogen in the tank is a positive sign, because at the end of the simulation the hydrogen in the tank is zero, which means that all produced hydrogen will have been sold.

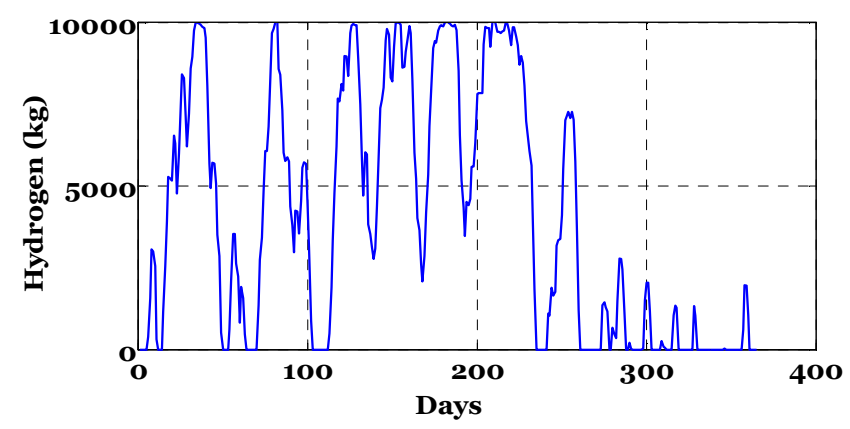

Fig. 7 yearly variation of hydrogen in the tank

\section{Garage forecourts with central electrolyser (with $20 \%$ profit margin)}

This scenario will directly affect the cost of the price of hydrogen without any clear impact on the amount of energy absorbed. In other words, the cost of the imported hydrogen will increase, which will directly lead to an increase in the price of hydrogen at the point of sale for each station. The central hydrogen price will be $36.32 £ / \mathrm{kg}$, and the average price of hydrogen at the garage forecourts will be 17.26, $19.80,15.84,15.54,18.62,18.08 £ / \mathrm{kg}$ for stations 1 to 6 , respectively. The difference between the revenue and the cost under the default price $(7.923 £ / \mathrm{kg})$ will be higher than other scenarios.

\section{DISCUSSION AND FUTURE WORK}

On-site hydrogen production at garage forecourts during off-peak times has been implemented to achieve a number of goals: balancing the grid by absorbing temporary surpluses of renewable energy, reducing the cost of hydrogen by choosing the cheapest electricity tariff, and guaranteeing the uninterrupted supply of hydrogen fuel. Six garage forecourts with different hydrogen consumptions have been investigated under different scenarios. In Scenario 1, hydrogen produced in a garage forecourt at off-peak times (and without the centralised electrolyser); and in Scenario 2, the central electrolyser will be integrated to the model to absorb the rest of energy and meet the requirements for hydrogen at times of shortage. In the second scenario, the result will be checked with and without $20 \%$ of the investment cost as a profit margin. The average hydrogen price in the first scenario is higher than the default price, which is one of the goals of this work, also other goals are not satisfied because nearly $46.07 \%$ of the 
excess power is not consumed and will cause instability within the grid. Also, this system could not provide fuel to customers without interruption, because nearly $40.18 \%$ of the demand is not satisfied. The last goal, which is the annual payment, doesn't satisfied since the differences are negative values. In the second scenario (with and without the profit margin), the absorbed energy reaches $78.83 \%$ and nearly $72.07 \%$ of the demand can be met. The average price of hydrogen is higher than the default price $(7.92 £ / \mathrm{kg})$, so this scenario cannot meet the annual economic requirements (bank installment and variable cost). The reason for these values is the high price of imported hydrogen, which was $32.25 £ / \mathrm{kg}$ (without profit margin) and $36.32 £ / \mathrm{kg}$ (with $20 \%$ profit margin). The central electrolyser simply calculates the average price of hydrogen based on the total annual cost and annual hydrogen production.

\section{REFRENCES}

[1] G. Saur and T. Ramsden, "Wind electrolysis: Hydrogen cost optimization," Contract, vol 303, pp. 275-3000, 2011.

[2] D. Steward, G. Saur, M. Penev and T. Ramsden, "Lifecycle cost analysis of hydrogen versus other technologies for electrical energy storage," NREL is a national laboratory of the U.S. Department of Energy, Cole Boulevard, Golden, Colorado, Tech. Rep. -560-46719, 2009.

[3] B. Biegel, L. H. Hansen, J. Stoustrup, P. Andersen and S. Harbo, "Value of flexible consumption in the electricity markets," Energy, vol 66, pp. 354-362, 2014.

[4] B. Olateju and A. Kumar, "Hydrogen production from wind energy in western canada for upgrading bitumen from oil sands," Energy, vol 36, no 11, pp. 6326-6339, 112011.

[5] J. G. Carton and A. G. Olabi, "Wind/hydrogen hybrid systems: Opportunity for ireland's wind resource to provide consistent sustainable energy supply," Energy, vol 35, no 12, pp. 4536-4544, 122010.

[6] E. Troncoso and M. Newborough, "Electrolysers for mitigating wind curtailment and producing 'green' merchant hydrogen," International journal of hydrogen energy, vol 36, no 1, pp. 120-134, 12011.

[7] E. Troncoso and M. Newborough, "Electrolysers for mitigating wind curtailment and producing 'green' merchant hydrogen," International journal of hydrogen energy, vol 36, no 1, pp. 120-134, 12011.

[8] F. Díaz-González, A. Sumper, O. Gomis-Bellmunt and R. Villafáfila-Robles, "A review of energy storage technologies for wind power applications," Renewable and sustainable energy reviews, vol 16, no 4, pp. 2154-2171, 52012.

[9] P. Floch, S. Gabriel, C. Mansilla and F. Werkoff, "On the production of hydrogen via alkaline electrolysis during offpeak periods," International journal of hydrogen energy, vol 32, no 18, pp. 4641-4647, 122007.
[10] T. Brown, S. Stephens-Romero and G. S. Samuelsen, "Quantitative analysis of a successful public hydrogen station," International journal of hydrogen energy, vol 37, no 17, pp. 12731-12740, 2012.

[11] M. Balat, "Potential importance of hydrogen as a future solution to environmental and transportation problems," International journal of hydrogen energy, vol 33, no 15, pp. 4013-4029, 2008.

[12] L. Zhao and J. Brouwer, "Dynamic operation and feasibility study of a self-sustainable hydrogen fueling station using renewable energy sources," International journal of hydrogen energy, vol 40, no 10, pp. 3822-3837, 2015.

[13] A. M. A. Mohamed, A. Al-Habaibeh and H. Abdo, "An investigation into the current utilisation and prospective of renewable energy resources and technologies in libya," Renewable energy, vol 50, no 0, pp. 732-740, 22013.

[14] A. Rahil, R. Gammon and N. Brown, , "Dispatchable hydrogen production at the forecourt for electricity grid balancing," In AIP conference proceedings, 2017, pp. 020011.

[15] A. Rahil, R. Gammon and N. Brown, "Techno-economic assessment of dispatchable hydrogen production by multiple electrolysers in libya," Journal of energy storage, vol 16, pp. 46-60, 42018.

[16] A. Rahil and R. Gammon, "Dispatchable hydrogen production at the forecourt for electricity demand shaping," Sustainability, vol 9, no 10, pp. 1785, 2017.

[17] P. Menanteau, M. Quéméré, A. Le Duigou and S. Le Bastard, "An economic analysis of the production of hydrogen from wind-generated electricity for use in transport applications," Energy policy, vol 39, no 5, pp. 2957-2965, 2011.

[18] L. Bertuccioli, A. Chan, D. Hart, F. Lehner, B. Madden and E. Standen, "Development of water electrolysis in the european union," E4tech Sàrl, Switzerland, Tech. Rep. Final Report, 2014.

[19] Y. Li, D. Chen, M. Liu and R. Wang, "Life cycle cost and sensitivity analysis of a hydrogen system using low-price electricity in china," International journal of hydrogen energy, 2017.

[20] J. Udie, S. Bhattacharyya and L. Ozawa-Meida, "A conceptual framework for vulnerability assessment of climate change impact on critical oil and gas infrastructure in the niger delta," Climate, vol 6, no 1, pp. 11, 2018. 